\title{
A different approach in thoracic surgery: Guillotine lobectomy
}

\author{
Göğüs cerrahisinde farklı bir yaklaşım: Giyotin lobektomi
}

\author{
Hüseyin Yıldıran $[$, Güven Sadi Sunam $[0$
}

Department of Thoracic Surgery, Medicine Faculty of Selçuk University, Konya, Turkey

\begin{abstract}
Background: In this study, we aimed to compare the surgical results of video-assisted thoracoscopic lobectomy with the guillotine technique to the results of conventional video-assisted thoracoscopic lobectomy.

Methods: Between January 2013 and December 2019, a total of 49 patients (20 males, 29 females; median age: 45 years; range, 11 to 73 years) who underwent video-assisted thoracoscopic lobectomy for benign lung pathologies were retrospectively analyzed. The patients were divided into two groups: the guillotine technique group $(n=31)$ who had simultaneous cutting of the lobar artery and lobar bronchus with a single stapler, and the control group $(n=18)$ who received conventional video-assisted thoracoscopic lobectomy. Demographic features of the patients, type of surgery, type of pulmonary resection, duration of the operation, postoperative length of hospital stay, postoperative pathological examination result, complications, and follow-up data were recorded.
\end{abstract}

Results: The median operation time was 142.5 (range, 60 to 237) min and 90 (range, 55 to 180) $\mathrm{min}$ in the control and the guillotine technique groups, respectively, indicating a statistically significant difference $(\mathrm{p}<0.05)$. Bronchiectasis was the most common histopathological diagnosis in both groups. No intraoperative complication, long-term complications or mortality were observed in any of the patients.

Conclusion: The guillotine lobectomy technique significantly reduces the duration of the operation. The adventitia and connective tissue around the lobar artery and lobar bronchus enable the closure of these structures with the supporting tissue and, therefore, reinforces the staples. The guillotine technique in video-assisted thoracoscopic lobectomy seems to be a cost-effective, reliable, and practical method that provides intraoperative convenience and shortens the operation time.

Keywords: Guillotine technique, lobectomy, surgery, video-assisted thoracoscopic surgery.

\section{$\ddot{O} Z$}

Amaç: Bu çalışmada giyotin tekniği ile yapılan video yardımlı torakoskopik lobektominin cerrahi sonuçları ile klasik video yardımlı torakoskopik lobektomi sonuçları karşılaştırıldı.

Çalışma planı: Ocak 2013 - Aralık 2019 tarihleri arasında, benign akciğer patolojileri nedeniyle video yardımlı torakoskopik lobektomi uygulanmış toplam 49 hasta (20 erkek, 29 kadın; medyan yaş: 45 yıl; dağılım, 11-73 yıl) retrospektif olarak incelendi. Hastalar iki gruba ayrıldı: lober arter ve lober bronşun tek stapler kullanılarak aynı anda kesildiği giyotin tekniği grubu $(n=31)$ ve klasik video yardımlı torakoskopik lobektomi yapılan kontrol grubu $(n=18)$. Hastaların demografik özellikleri, cerrahi türü, akciğer rezeksiyonu türü, cerrahi süresi, ameliyat sonrası hastanede yatış süresi, ameliyat sonrası patoloji sonucu, komplikasyonlar ve takip verileri kaydedildi.

Bulgular: Kontrol ve giyotin tekniği gruplarında medyan ameliyat süresi sırasıyla 142.5 (dağılım, 60-237) dk. ve 90 (dağılım, 55-180) dk olup, istatistiksel olarak anlamlı bir fark $\operatorname{vard}_{1}(\mathrm{p}<0.05)$. Bronşektazi, her iki grupta da en sık histopatolojik tanı idi. Hastaların hiçbirinde ameliyat sırasında komplikasyon, uzun dönem komplikasyon veya mortalite gözlenmedi.

Sonuç: Giyotin lobektomi tekniği ameliyat süresini anlamlı olarak azaltır. Lober arter ve lober bronş çevresindeki adventisya ve bağ doku, arter ve bronşun stapler ile kapanmasını sağlayarak, stapleri güçlendirir. Video yardımlı torakoskopik lobektomide giyotin tekniği ameliyatı kolaylaştıran ve ameliyat süresinin kısalmasını sağlayan düşük maliyetli, güvenilir ve pratik bir yöntem olarak görünmektedir.

Anahtar sözcükler: Giyotin tekniği, lobektomi, cerrahi, video yardımlı torakoskopik cerrahi.

Received: September 30, 2020 Accepted: March 31, 2021 Published online: October 20, 2021

Correspondence: Hüseyin Yıldıran, MD. Selçuk Üniversitesi Tıp Fakültesi Göğüs Cerrahisi Anabilim Dalı, 42130 Selçuklu, Konya, Türkiye. Tel: +90 332 - 2243929 e-mail: h-yildiran@hotmail.com 
Lobectomies performed with video-assisted thoracoscopic surgery (VATS) are proven to be superior to lobectomies performed by thoracotomy, and VATS have become widely used in surgical interventions characterized by fewer surgical incisions and rapid recovery times. ${ }^{[1]}$ With the development of technology, progress has been made in VATS lobectomy techniques, and its use has become routine.

In this study, we developed the "guillotine technique" in which the lobar artery and bronchus were divided with a single stapler at the same time in patients who underwent VATS lobectomy. Our aim was to compare the results of the guillotine technique with the conventional videothoracoscopic lobectomies in patients undergoing thoracic surgery.

\section{PATIENTS AND METHODS}

This single-center, retrospective study was conducted at Medicine Faculty of Selçuk University, Department of Thoracic Surgery between January 2013 and December 2019. A total of 49 patients (20 males, 29 females; median age: 45 years; range, 11 to 73 years) who underwent VATS lobectomy for benign lung pathologies were included. All VATS lobectomies due to primary and secondary lung cancer

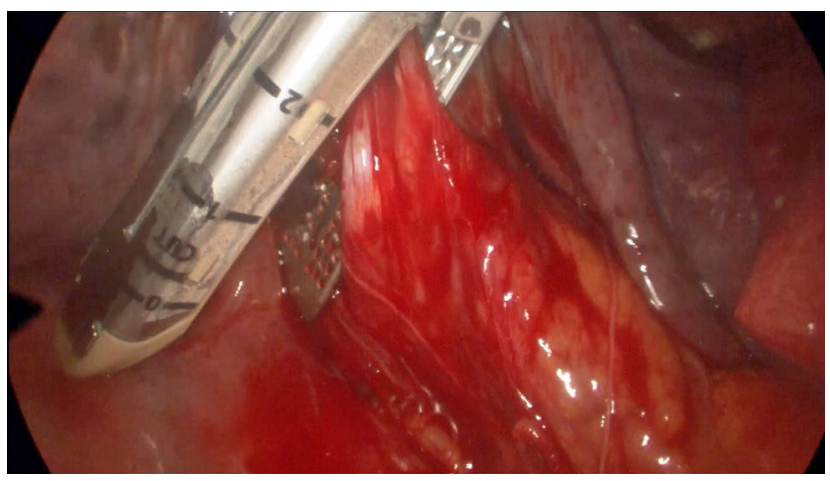

Figure 1. The intraoperative view: Pulmonary vein (right lower lobe) was divided with a vascular 30-mm staple.

and trauma and lung resections with thoracotomy were excluded. The patients were divided into two groups: the guillotine stapler technique group $(n=31)$ in which the lobar artery and lobar bronchus were divided with a single and same stapler at the same time, and the control group $(n=18)$ undergoing conventional VATS lobectomy. Operation time, hospitalization time, and complications were compared between the groups. Demographic features of the patients, type of surgery, type of pulmonary resection, duration of the operation, postoperative hospital stay, postoperative

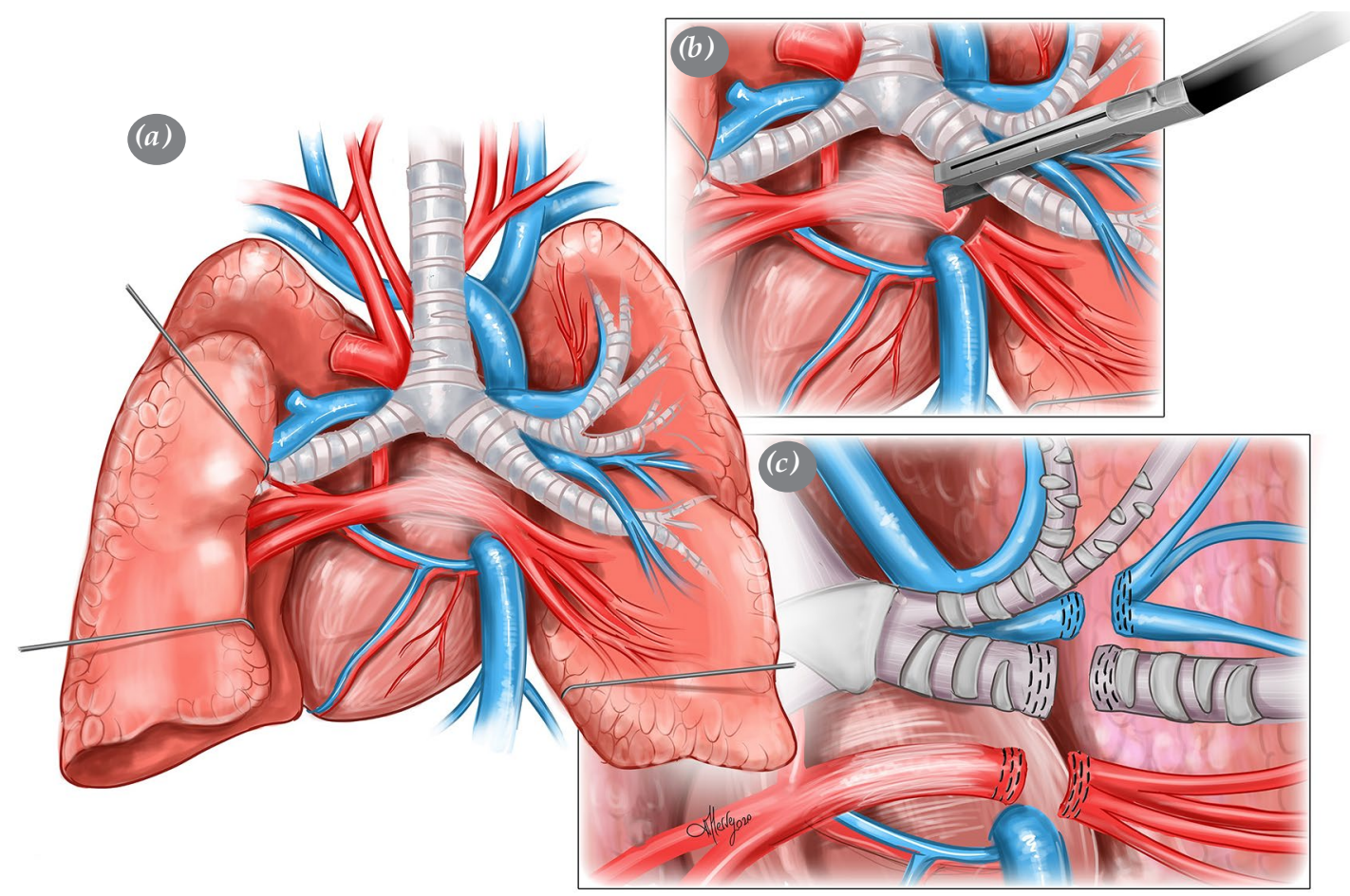

Figure 2. (a) Illustration of pulmonary vascular and bronchial structures (posterior view). (b) The dividing the lobar artery and lobar bronchus together with the same staple. (c) Illustrative image of the lobar vein, artery and bronchus after firing the staple. 

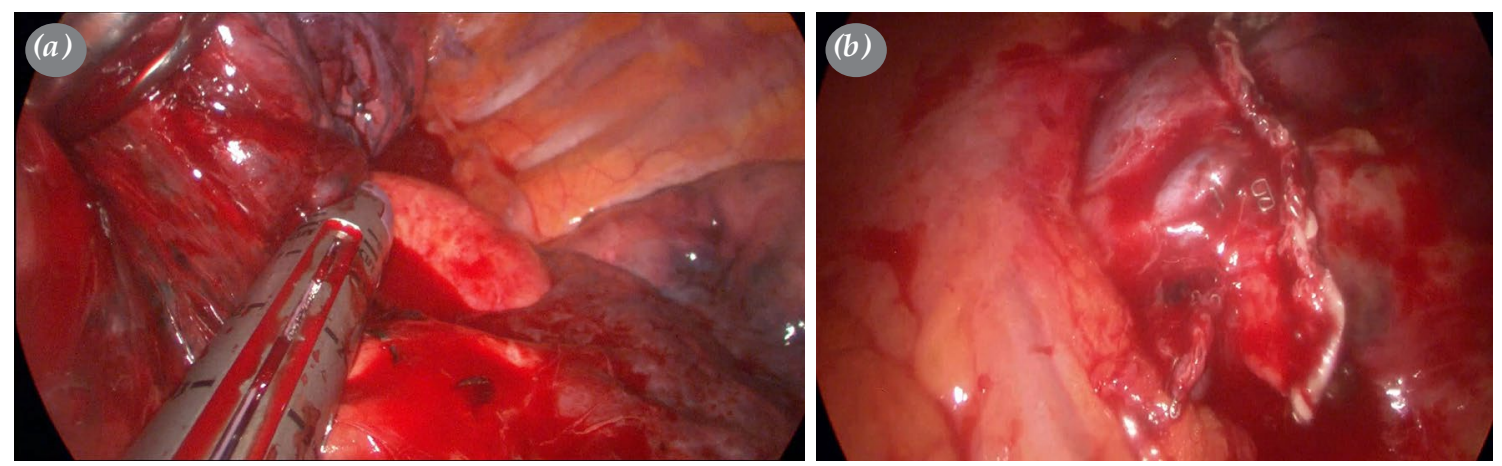

Figure 3. (a) The intraoperative view of dividing the artery and bronchus together with 60-mm staple. (b) The image of lobar hilus after left upper lobectomy.

pathology, complications, and follow-up were recorded. A written informed consent was obtained from each patient. The study protocol was approved by the Medicine Faculty of Selçuk University Local Ethics Committee (No: 2020/247). The study was conducted in accordance with the principles of the Declaration of Helsinki.

\section{Conventional stapler technique (control group)}

The vein, artery, and bronchus of the lobe planned to be resected were dissected and divided separately using 60-mm purple staples (EndoGIA ${ }^{\mathrm{TM}}$ Medtronic; Covidien, Mansfield, MA, USA) for the bronchus and $30-\mathrm{mm}$ white staples (EndoGIA ${ }^{\mathrm{TM}}$ Medtronic; Covidien, Mansfield, MA, USA) for the vessels.

\section{Guillotine stapler technique}

The lobe vein was dissected and divided by using a $30-\mathrm{mm}$ white stapler (EndoGIA ${ }^{\mathrm{TM}}$ Medtronic; Covidien, Mansfield, MA, USA) (Figure 1) and, then, both the artery and the bronchus were dissected and divided together by firing a $60-\mathrm{mm}$ purple Tri-Staple $^{\mathrm{TM}} \quad$ (EndoGIA $^{\mathrm{TM}}$ Medtronic; Covidien Mansfield, MA, USA) in the guillotine stapler technique (Figures 2 and 3).

\section{Statistical analysis}

Statistical analysis was performed using the IBM SPSS version 25.0 software

Table 1. Demographic characteristics of patients

\begin{tabular}{lccccc}
\hline & \multicolumn{2}{c}{ Guillotine group } & & \multicolumn{2}{c}{ Conventional group } \\
\cline { 2 - 3 } \cline { 6 - 7 } & $\mathrm{n}$ & Mean \pm SD & & $\mathrm{n}$ & Mean \pm SD \\
\hline Male & 14 & $44.5 \pm 17.8$ & & 6 & $50 \pm 17.6$ \\
Female & 17 & $38.4 \pm 13.5$ & & 12 & $40.4 \pm 15.1$ \\
Total & 31 & $41.2 \pm 15.6$ & & 18 & $43.6 \pm 16.1$ \\
\hline
\end{tabular}

(IBM Corp., Armonk, NY, USA). Descriptive data were expressed in mean \pm standard deviation (SD), median (min-max) or number and frequency. The normal distribution of univariate data was evaluated using the Shapiro-Francia test. The Mann-Whitney U test was used with Monte Carlo results for the comparison of two independent groups, according to quantitative data. The Fisher's exact test was used for the comparison of categorical variables. A $p$ value of $<0.05$ was considered statistically significant.

\section{RESULTS}

Demographic characteristics of the patients are shown in Table 1. The most common complaint was cough in $28(57.1 \%)$ patients.

The guillotine stapler technique was used in $31(63.2 \%)$ cases, and the conventional stapler technique was used in $18(36.8 \%)$ cases. A lower lobectomy, 15 on the right and 18 on the left side with a total of $33(67.3 \%)$ cases was the most common

Table 2. Type of pulmonary resection

\begin{tabular}{lccc}
\hline & $\begin{array}{c}\text { Guillotine } \\
\text { group }\end{array}$ & & $\begin{array}{c}\text { Conventional } \\
\text { group }\end{array}$ \\
\cline { 2 - 3 } Resected part & $\mathrm{n}$ & & $\mathrm{n}$ \\
\hline Right upper lobectomy & 2 & & 0 \\
Right lower lobectomy & 11 & 4 \\
Left upper lobectomy & 1 & 0 \\
Left lower lobectomy & 13 & 5 \\
Right middle lobectomy & 1 & 5 \\
Lingular resection & 1 & \\
Bilobectomy inferior & 1 & \\
Bilobectomy superior & 1 & & 1 \\
\hline
\end{tabular}


operation (Table 2). No intraoperative complication was observed in either group, and no case required conversion to thoracotomy. Postoperative intensive care was not required in any of the patients.

The median operation time was 142.5 (range, 60 to 237) min and 90 (range, 55 to 180) $\mathrm{min}$ in the control and the guillotine technique groups, respectively, indicating a statistically significant difference $(\mathrm{p}<0.05)$ (Table 3, Figure 4).

The median postoperative length of hospitalization was 6.5 (range, 4 to 43) days and 7 (range, 3 to 26) days in the control and guillotine stapler technique groups, respectively. In the control and guillotine stapler technique groups, complications were found in two (11.1\%) and five $(16.1 \%)$ cases, respectively, within the first three months after surgery (Table 4). There was no statistically significant difference between the two groups in terms of hospitalization time and complications ( $p>0.05)$. Bronchiectasis was the most

Table 4. Postoperative complications within the first three months

\begin{tabular}{lccccc}
\hline & $\begin{array}{c}\text { Guillotine } \\
\text { group }\end{array}$ & $\begin{array}{c}\text { Conventional } \\
\text { group }\end{array}$ & & Total \\
\cline { 2 - 3 } \cline { 5 - 6 } Complication & $\mathrm{n}$ & & $\mathrm{n}$ & & $\mathrm{n}$ \\
\hline Prolonged air leak & 1 & & 1 & & 2 \\
Pneumothorax & 1 & & 1 & & 2 \\
Atelectasis & 1 & & 0 & & 1 \\
Pneumonia & 1 & & 0 & & 1 \\
Pleural effusion & 1 & & 0 & & 1 \\
Total & 5 & & 2 & \\
\hline
\end{tabular}

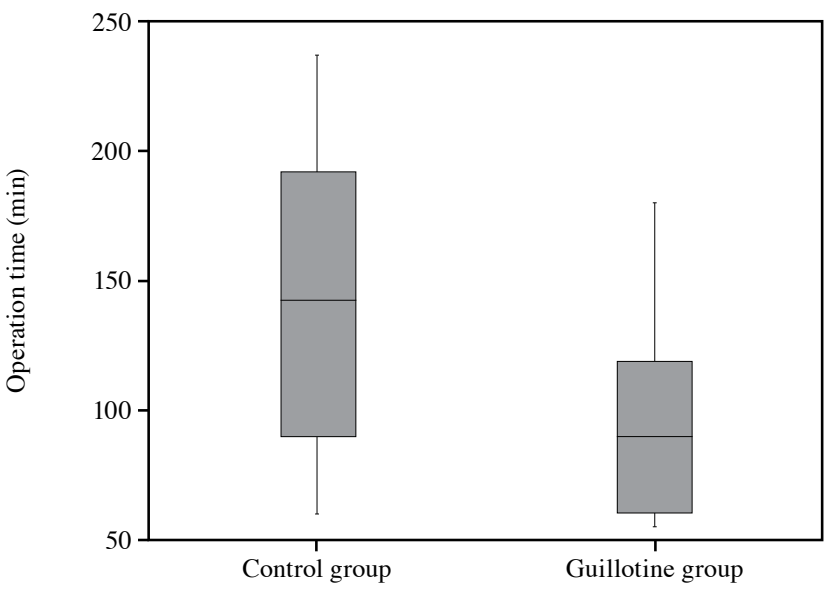

Figure 4. The operation time of two groups. 
Table 5. Histopathological examination results

\begin{tabular}{lcccc}
\hline & Guillotine group & & Conventional group & Total \\
\cline { 5 - 5 } Pathology & $\mathrm{n}$ & & $\mathrm{n}$ & $\mathrm{n}$ \\
\hline Bronchiectasis & 20 & & 15 & 35 \\
Congenital cystic adenomatoid malformation & 2 & 0 & 3 \\
Bronchogenic cyst & 2 & 0 & 2 \\
Abscess & 1 & 0 & 2 \\
Aspergillosis & 1 & 1 & 2 \\
Hamartoma & 0 & 1 & 2 \\
Necrotizing granuloma & 1 & 1 & 1 \\
Atypical adenomatoid hyperplasia & 1 & 0 & 1 \\
Bronchiolitis obliterans organized pneumonia (BOOP) & 31 & 0 & 1 \\
Total & 2 & 18 & 49 \\
\hline
\end{tabular}

common histopathological diagnosis in both groups (Table 5). The median follow-up was 33 (range, 6 to 79) months and 24 (range, 6 to 53) months for the control and guillotine technique groups, respectively. There were no long-term complications or mortality.

\section{DISCUSSION}

Benign lung diseases are usually accompanied by inflammation or occur with secondary infection. Therefore, peribronchial hyperplasic lymph nodes due to chronic bronchitis or pneumonia, adhesions between the artery and bronchus, and hypertrophy of the bronchial arteries are observed. ${ }^{[2]}$ Conglomerated lymph nodes negatively affect the dissection of the artery and bronchus in the lobar hilus. The hilus becomes more rigid with the lymph nodes containing calcification. In these cases, there is a high risk of complications, such as bleeding during hilus dissection. ${ }^{[3]}$ Therefore, conversion to an open thoracotomy is very likely for these cases.

Historically, the first VATS lobectomy was reported by Giancarlo Roviaro, $\mathrm{MD}^{[4,5]}$ and the first simultaneous stapled lobectomy was reported by Lewis et al. ${ }^{[6]}$ In the Lewis' technique, the lobar vessels and bronchus were stapled together simultaneously. However, it could not be safer for the classical oncological lobectomy. Also, there were "en masse" or "simultaneous stapled" lobectomy techniques as described in the literature. ${ }^{[7,8]}$ Dividing the lobar pulmonary vein firstly is the main difference of guillotine lobectomy from the described techniques. The artery and bronchus are stapled together. From this point of view, it can be performed in oncological surgery, even in malignant peripheral pulmonary nodules. Therefore, the guillotine technique is not a partial repetition of the origins of the lobectomy, but a superior modification of it, particularly in terms of the operation time.

The operation time for VATS lobectomy is approximately $180 \mathrm{~min}$ or longer. ${ }^{[9-11]}$ It has been shown that the guillotine stapler technique significantly reduces the operation time in VATS lobectomy, thereby, reducing the time of general anesthesia. ${ }^{[12,13]}$

In the literature, the average length of hospital stay after VATS lobectomy has been reported as less than seven days..$^{[9,11]}$ In this study, the median length of hospital stays of both groups are consistent with the literature. Although the median length of hospital stay in the guillotine technique group was less than in the control group, it did not reach statistical significance. This result can be attributed to the fact that the presented technique does not cause a difference to change the length of hospital stay. In terms of postoperative complications, the absence of a significant difference with classical VATS lobectomy results also makes the guillotine stapler technique suitable for use.

Furthermore, using a number of endoscopic staplers in guillotine lobectomy makes the operation more cost-effective. While VATS lobectomies performed with the guillotine stapler technique require two staples, conventional VATS lobectomy requires three staples at least. Therefore, the lesser staples cause lesser cost. 
Since the lobar artery and the bronchus lie together in the hilus, they can be dissected from the parenchyma at the same time, and divided with the same stapler in a single maneuver. This eliminates the risk of bleeding from the dissection of the hilus and, therefore, the possibility of conversion to thoracotomy, which enables an uneventful surgery. The guillotine stapler technique can be easily performed by any surgeon accustomed to VATS lobectomies, the learning curve is shorter than in conventional technique, and does not require more surgical ability than conventional lobectomies. Also, in cases where there is adhesion due to hilar calcific lymph nodes, the artery and bronchus can be safely divided with staples without having to separate them. ${ }^{[14]}$ Stabilization of both the vessel and bronchus together enables the closure of these structures with the supporting tissue provided by the adventitia and connective tissue around these structures, which acts as a stapler reinforcer. Another advantage is protection of the vein against intimal damage and vascular avulsion due to staple.

Bronchovascular fistulas are frequently presented as case reports in the literature, and their common points are mechanical stress applied to the vessel and/or local infection. ${ }^{[15]}$ In the technique applied in this study, no mechanical stress was applied to the vessel. Moreover, the tissues between the vascular and bronchial structures separate the artery and the bronchus and act as a physical barrier ${ }^{[16]}$ Extravascular and extrabronchial structures such as pleura, lymphatic tissue, and periadventitial tissues act as buttresses. We believe that these anatomical structures not only strengthen the staple line by providing additional support like a pledgeted suture, but also prevent the bronchovascular fistula functioning as a barrier between artery and bronchus.

The fact that the lobar veins are separate structures from the hilus allows them to be divided separately. However, while performing lobectomy with the guillotine technique, remaining lobar arteries and bronchial branches should be protected during the division of the artery and bronchus. Therefore, lower lobectomies are relatively easy and feasible resections in the guillotine technique. During upper and middle lobectomy, the arteries of the remaining lobes must be exposed and protected. Ventilation of the remaining parenchyma must be also confirmed following the closure of the stapler.

Currently, VATS lobectomy is a safe and feasible surgical approach with low morbidity and mortality. ${ }^{[17,18]}$ The development of technology would lead to the diversification of techniques in surgeries such as VATS lobectomy, which closely involve technology.

The limitations of this study are that it has a retrospective and single-center design. Further largescale, prospective studies are needed to confirm these findings.

In conclusion, while performing anatomical lung resection in benign inflammatory lung diseases, dissection and separate division of the artery and bronchus can be very difficult due to severe hilar adhesion and incomplete fissures. In such cases, the guillotine technique can be implemented as a plan $\mathrm{B}$ and is reliable, and this practical method provides intraoperative convenience and shortens the operation time.

\section{Acknowledgement}

We thank Merve Evren, PhD for the artwork in Figure 2.

\section{Declaration of conflicting interests}

The authors declared no conflicts of interest with respect to the authorship and/or publication of this article.

\section{Funding}

The authors received no financial support for the research and/or authorship of this article.

\section{REFERENCES}

1. Long H, Tan Q, Luo Q, Wang Z, Jiang G, Situ D, et al. Thoracoscopic surgery versus thoracotomy for lung cancer: Short-term outcomes of a randomized trial. Ann Thorac Surg 2018;105:386-92.

2. Mauchley DC, Mitchell JD. Surgery for bronchiectasis. In: Sugarbaker DJ, Bueno R, Colson YL, Jaklitsch M, Krasna MJ, Mentzer SJ, editors. Adult chest surgery. 2nd ed. New York: McGraw-Hill; 2015. p. 776-83.

3. Liu C, Ma L, Pu Q, Mei J,Liao H, Zhu Y, et al. Troubleshooting complicated hilar anatomy via prophylactically clamping the pulmonary artery: Three videos demonstrating three techniques. Ann Transl Med 2018;6:365.

4. Roviaro G, Rebuffat C, Varoli F, Vergani C, Mariani C, Maciocco M. Videoendoscopic pulmonary lobectomy for cancer. Surg Laparosc Endosc 1992;2:244-7.

5. Hytych V, Horazdovsky P, Pohnan R, Pracharova S, Taskova A, Konopa Z, et al. VATS lobectomy, history, indication, contraindication and general techniques. Bratisl Lek Listy 2015;116:400-3.

6. Lewis RJ, Caccavale RJ, Bocage JP, Widmann MD. Videoassisted thoracic surgical non-rib spreading simultaneously stapled lobectomy: A more patient-friendly oncologic resection. Chest 1999;116:1119-24.

7. Kamiyoshihara M, Igai $\mathrm{H}$, Ibe $\mathrm{T}$, Ohtaki $\mathrm{Y}$, Atsumi J, Nakazawa $S$, et al. Pulmonary lobar root clamping and stapling technique: Return of the "en masse lobectomy". Gen Thorac Cardiovasc Surg 2013;61:280-91. 
8. Qiang G, Nakajima J. Simultaneous stapling of pulmonary vein and bronchus in video-assisted thoracic surgery lobectomy. Ann Thorac Cardiovasc Surg 2015;21:78-80.

9. Mafé JJ, Planelles B, Asensio S, Cerezal J, Inda MD, Lacueva $\mathrm{J}$, et al. Cost and effectiveness of lung lobectomy by videoassisted thoracic surgery for lung cancer. $\mathrm{J}$ Thorac Dis 2017;9:2534-43.

10. Cai YX, Fu XN, Xu QZ, Sun W, Zhang N. Thoracoscopic lobectomy versus open lobectomy in stage I non-small cell lung cancer: A meta-analysis. PLoS One 2013;8:e82366.

11. Sihoe AD. Reasons not to perform uniportal VATS lobectomy. J Thorac Dis 2016;8(Suppl 3):S333-43.

12. Bläss J, Staender S, Moerlen J, Tondelli P. Complicationfree early extubation following abdomino-thoracic esophagectomy. Anaesthesist 1991;40:315-23.

13. Hsu H, Lai HC, Liu TJ. Factors causing prolonged mechanical ventilation and peri-operative morbidity after robot-assisted coronary artery bypass graft surgery. Heart Vessels 2019;34:44-51.
14. Liu C, Ma L, Pu Q, Liao H, Liu L. How to deal with benign hilar or interlobar lymphadenopathy during video-assisted thoracoscopic surgery lobectomy-firing the bronchus and pulmonary artery together. J Vis Surg 2016;2:26.

15. Knight J, Elwing JM, Milstone A. Bronchovascular fistula formation: A rare airway complication after lung transplantation. J Heart Lung Transplant 2008;27:1179-85.

16. Kawahara K, Akamine S, Takahashi T, Nakamura A, Muraoka M, Tsuji H, et al. Management of anastomotic complications after sleeve lobectomy for lung cancer. Ann Thorac Surg 1994;57:1529-32.

17. Baysungur V, Dogruyol T, Ocakcioglu I, Misirlioglu A, Evman S, Kanbur S, et al. The feasibility of thoracoscopic resection in bronchiectasis. Surg Laparosc Endosc Percutan Tech 2017;27:194-6.

18. Fındık G, İncekara F, Demiröz M, Sayılır E, İnan K, Hazer $\mathrm{S}$, et al. First experiences and complications in video-assisted thoracoscopic surgery lobectomy at a thoracic surgery center. Turk Gogus Kalp Dama 2018;26:116-22.. 